\title{
A FEBRASGO e a Integração com o Conselho Federal de Medicina e o Ministério da Saúde
}

Durante a Assembléia Geral das Federadas, realizada em Manaus, em julho de 2000, estiveram presentes o Presidente do Conselho Federal de Medicina e representantes do Ministério da Saúde. Foram relatadas, e enaltecidas, as parcerias já efetivadas com estes órgãos para ações em prol da saúde da mulher. Os representantes de ambas as Instituições salientaram o papel que a FEBRASGO, representante oficial dos Ginecologistas e Obstetras brasileiros, tem tido como exemplo às demais sociedades científicas da Associação Médica Brasileira, na abrangência que tem dado às suas ações.

Para que estes projetos e parcerias sejam culminados de pleno êxito, entretanto, não bastam apenas as atuações da Diretoria da FEBRASGO e dos órgãos envolvidos, mas também de todas as Federadas e, principalmente, do imprescindível apoio dos associados.

\section{A Diretoria}

